\title{
KEPUASAN MAHASISWA TERHADAP MUTU PELAYANAN STAF ADMINISTRASI KEUANGAN DI AKADEMI KEPERAWATAN DIRGAHAYU SAMARINDA
}

\author{
Yovita Erin Sastrini \\ STIKES Dirgahayu Samarinda \\ Jl. Pasundan No.21, Jawa, Samarinda Ulu, Kota Samarinda \\ y.erinsastrini@yahoo.com
}

\begin{abstract}
The purpose of the study was to reveal student satisfaction with total service, service dimensions, and items of service for administrative staff in the financial section of Akper Dirgahayu. This research is a quantitative descriptive study that describes student satisfaction with financial administration services. The study was conducted from November and December 2016 at the Campus of Nursing Academy in Samarinda.

The research subjects were second-level students, amounting to 185 people, and the object of the study was student satisfaction with the quality of financial part administration services at Akper Dirgahayu. Data collection uses a Likert 4 choice satisfaction questionnaire developed from 5 dimensions of service quality, namely tangibles, responsiveness, reliability, empathy, and assurance. Analysis of data describing student satisfaction with service is carried out using the Student Satisfaction Index (IKM) and percentage distribution table.

The results showed that (1) student satisfaction with the service of the administrative staff of the financial section of Akper Dirgahayu belonged to the category of satisfaction, the student satisfaction index value (IKM) for the total service was 68.90 (classified as satisfied) and about 70 percent of students had satisfaction scores classified as categories satisfied and very satisfied; (2) Satisfaction with all dimensions of service and for all service items also has the value of SMIs classified as satisfied; and (3) there are a number of items including potential perceived dissatisfaction by students. These items are friendliness, ease of meeting officers, alertness asking for needs, speed of service, convenience / suitability of service procedures, officer justice, willingness of officers to help difficulties, accuracy of officer appointments, every service request is always fulfilled, and the ability of officers to provide solutions. Each of these items was perceived as dissatisfied and very dissatisfied with more than 30 percent of students.
\end{abstract}

Keywords: Student Satisfaction, Quality of Financial Administration Staff Services

\section{PENDAHULUAN}

Kesadaran masyarakat tentang pentingnya pendidikan terutama pendidikan tinggi yang merupakan wadah pembentukan sumber daya manusia yang bermutu, menyebabkan minat masyarakat terhadap pendidikan tinggi semakin meningkat. Manajemen pendidikan tinggi tak ubahnya sebuah perusahaan di mana perguruan tinggi sebagai produsen dan mahasiswa sebagai konsumen. Dalam peran seperti itu, sebuah perguruan tinggi dituntut terus-menerus meningkatkan kinerja dan kualitas pelayanannya sehingga mampu bersaing dengan lembaga pendidikan serupa lainnya.
Tuntutan terhadap perguruan tinggi dan secara khusus terhadap fakultas, bukan hanya sebatas kemampuan untuk menghasilkan lulusan yang didasarkan pada prestasi akademik semata, melainkan keseluruhan program pendidikan dari lembaga-lembaga perguruan tinggi harus mampu membuktikan kualitas yang tinggi seperti yang tercermin dalam akuntabilitas, bukti prestasi, penilaian, sertifikasi kualitas, dan keberhasilan alumni dalam mendapatkan pekerjaan. Kesemuanya itu ditentukan oleh profesionalisme dalam memberikan jasa/ layanan akademik maupun layanan administratif kepada mahasiswa. 
Urgensi profesionalisme dalam memberikan pelayanan bagi suatu perguruan tinggi tidak hanya terkait dengan kualitas lulusan, tetapi juga sebagai modal promosi menarik peminat dalam hal ini adalah calon-calon mahasiswa. Perguruan tinggi yang terindikasi asalasalan memberikan pelayanan, butuh biaya besar untuk promosi ke masyarakat atau bukan tidak mungkin akan ditinggalkan oleh peminat atau mungkin hanya dipilih oleh peminat yang tidak tertampung di perguruan tinggi lainnya. Bila itu yang terjadi, maka perguruan tinggi yang bersangkutan akan dirugikan sebab memiliki raw input (faktor masukan) rendah yang pada gilirannya akan menghasilkan raw ouput (keluaran) yang juga berkualitas rendah dan hal tersebut merupakan ancaman terhadap eksistensi/keutuhan manajemen pengelolaan.

\section{TINJAUAN PUSTAKA}

Selama ini, modal utama yang dipakai sebuah perguruan tinggi dalam promosi menarik minat masyarakat adalah penilaian kualitas yang dilakukan oleh BAN-PT. Hal itu tidak cukup sebab titik sentral pengelolaan perguruan tinggi adalah mahasiswa sebagai pelanggan utamanya. Selain sebagai pelanggan, mahasiswa sekaligus adalah anggota masyarakat. Dalam peran ganda seperti itu, maka informasi akurat tentang kredibilitas sebuah perguruan tinggi lebih cepat tersebar ke masyarakat luas melalui mahasiswa, lebih-lebih setelah mereka lulus. Sehingga, sangat penting bagi pengelola fakultas dan perguruan tinggi untuk mendapatkan umpan balik (feedback) tentang kualitas jasa yang diberikan dari sudut pandang penilaian mahasiswa. Seperti yang dikemukakan oleh Kotler (2009) bahwa kualitas harus dimulai dan berakhir pada pelanggan.

Dalam pengelolaan suatu perguruan tinggi, hal yang mungkin terjadi dan berpotensi besar menimbulkan ketidakpuasan bagi mahasiswa antara lain fasilitas kampus tidak memadai, dosen tidak berkompeten, dosen sering tidak hadir, staf administrasi sering tidak ada di tempat, staf administrasi tidak ramah dalam memberikan pelayanan, dan hal-hal lainnya. Maka pihak pimpinan manajemen dituntut menerapkan konsep manajemen yang menekankan pada pencarian secara konsisten terhadap perbaikan yang berkelanjutan untuk mencapai kebutuhan dan kepuasan pelanggan dalam hal ini adalah mahasiswa dan civitas akamedika lainnya.

Akademi Keperawatan (Akper) Dirgahayu adalah satu di antara beberapa lembaga pendidikan di Samarinda yang menghasilkan sumber daya perawat. Perguruan tinggi swasta ini cikal bakalnya adalah Sekolah Perawat Kesehatan Dirgahayu di bawah Yayasan Setia Budi tahun 1983 dan berubah status menjadi akademi keperawatan tahun 2000 dengan mengemban visi "Pada Tahun 2020 Menghasilkan Perawat Profesional, Penuh Cinta Kasih dan Mampu Bersaing Secara Nasional". Guna mewujudkan visi tersebut, maka penyelenggaraan pendidikan spesifik diarahkan bertujuan untuk menghasilkan perawat profesional pemula yang kompeten dalam memberikan asuhan keperawatan sesuai dengan kewenangannya, menerapkan perinsip manajemen asuhan keperawatan, berperan serta dalam penelitian keperawatan dan menggunakan hasil penelitian dalam asuhan keperawatan, dan mengembangkan kemampuan profesional secara terus menerus.

Tujuan penyelenggaran pendidikan tersebut menjadi keunggulan kompetitif Akper Dirgahayu dalam persaingan dengan lembaga pendidikan sejenis. Penyelenggaran pendidikan ditunjang oleh sarana dan prasarana yang lengkap, para dosen berpendidikan minimal S2 Keperawatan dan atau S2 Kesehatan dengan latar belakang pendidikan Ners, memiliki Nomor Induk Dosen Nasional (NIDN), memiliki jabatan fungsional akademik minimal lektor, memiliki 
sertifikat PEKERTI, dan atau AA (Ancangan aplikasi), berpengalaman klinik minimal 2 tahun di bidang keperawatan, kreatif, dedikatif, inovatif dan berkomitmen tinggi untuk terlibat secara aktif dalam proses pembelajaran mahasiswa baik di kelas maupun di wahana klinik dan komunitas, memiliki sertifikat dosen profesional, menghasilkan karya ilmiah yang dipublikasikan, memiliki integritas diri dapat menjadi model sebagai dosen professional. Sehingga fasilitas (sarana dan prasarana) kampus dan kompetensi dosen bukan merupakan hal yang dikuatirkan akan menimbulkan ketidakpuasan. Demikian juga dengan kehadiran dosen dan karyawan, pihak manajemen Akper Dirgahayu telah menerapkan daftar hadir dan sanksi secara ketat.

Hal yang masih belum diketahui secara pasti adalah kualitas/mutu dari pelayanan yang diberikan oleh para staf administrasi kepada mahasiswa. Terkadang ada keluhan segelintir mahasiswa setelah berinteraksi dengan staf administrasi khususnya bagian keuangan yang mana keluhan tersebut sudah barang

\section{METODE PENELITIAN}

\section{A. Jenis Penelitian}

Penelitian ini adalah penelitian deskriptif kuantitatif yang mendeskripsikan kepuasan mahasiswa terhadap pelayanan admintrasi keuangan; deskripsi kepuasan terhadap total pelayanan, terhadap dimensi pelayanan, dan terhadap item-item pelayanan; dengan menggunakan indeks kepuasan dan distribusi persentase.

B. Tempat dan Waktu

Penelitian dilaksanakan dari bulan Nopember dan Desember 2016 di Kampus Akademi Keperawatan Dirgahayu Samarinda.

\section{Subyek dan Obyek Penelitian}

Subyek penelitian adalah mahasiswa tingkat dua yang berjumlah 185 orang, dan yang menjadi obyek penelitian adalah tentu adalah manifestasi dari ketidakpuasan. Namun hal itu belum bisa menggeneralisasi kualitas pelayanan para staf administrasi bagian keuangan secara umum sebab kejadiannya kusuistik; mungkin karena miskomunikasi/kesalahpaman atau mahasiswa menuntut pelayanan yang lebih sementara petugas memiliki keterbatasan dan sudah bekerja sesuai aturan, atau karena faktor-faktor lain. Oleh karena itu perlu kajian ilmiah tentang kepuasan mahasiswa terhadap pelayanan staf adminstrasi bagian keuangan secara menyeluruh; terhadap total pelayanan, terhadap dimensi pelayanan, dan terhadap item-item pelayanan.

Rumusan permasalahan dalam peneliti ini adalah bagaimana kepuasan mahasiswa terhadap pelayanan staf administrasi bagian keuangan Akper Dirgahayu?

Tujuan penelitian adalah untuk mengungkap kepuasan mahasiswa terhadap total pelayanan, dimensi pelayanan, dan item-item pelayanan staf administrasi bagian keuangan Akper Dirgahayu.

kepuasan mahasiswa terhadap mutu pelayanan admintrasi bagian keuangan Akper Dirgahayu.

D. Definisi Operasional

Kepuasan mahasiswa terhadap pelayanan admintrasi keuangan adalah kesesuaian harapan atau hal yang dirasakan oleh mahasiswa dengan perlakuan yang diterimanya ketika menerima layanan pada bagian admintrasi keuangan Akper Dirgahayu. Secara operasionalnya adalah tanggapan/persepsi mahasiswa terhadap item-item pelayanan yang dinyatakan dengan skor angket skala kepuasan.

E. Teknik Pengumpulan Data

Pengumpulan data penelitian menggunakan angket kepuasan skala Likert 4 pilihan yang dikembangkan dari 5 dimensi mutu pelayanan yaitu berwujud (tangibles), daya tanggap (responsiveness), 
kehandalan (reliability), empati (emphaty), dan keyakinan (assurance).

F. Teknik Analisis Data

Gambaran tentang kepuasan mahasiswa terhadap pelayanan dilakukan dengan menggunakan Indeks Kepuasan Mahasiswa (IKM) dan tabel distribusi persentase.

Perhitungan IKM mengadopsi prosedur perhitungan Indeks Kepuasan Masyarakat (Evaluasi Pengguna Jasa) Universitas Brawijaya tahun 2012. Pengumpulan data menggunakan angket kepuasan berskala $1-4$, maka nilai dasar IKM yang digunakan adalah 25 dan interval nilai IKM yang mungkin adalah 25 - 100. Dari tabulasi data, dihitung nilai rata-rata masing-masing item yang terdiri 15 item, rumusnya adalah :

\author{
$N R R_{i}=$ \\ Jumlah skor item $k e-i$ \\ banyaknya mahasiswa yang menjawab item ke-i
}

IKM terhadap masing-masing item pelayanan dihitung dengan rumus :

$$
I K M_{i}=N R R_{i} \times 25
$$

IKM terhadap masing-masing dimensi pelayanan adalah rata-rata $I K M_{i}$ pada setiap dimensi pelayanan dan IKM terhadap total pelayanan adalah rata-rata keseluruhan $I K M_{i}$.

Penilaian kualitatif kepuasan mahasiswa terhadap pelayanan dan mutu pelayanan (per-item pelayanan, perdimensi pelayanan dan total pelayanan), didasarkan pada Tabel 1 berikut :

Tabel 1. Pedoman Penilaian Kualitatif Kepuasan dan Mutu Layanan Berdasarkan nilai IKM

\begin{tabular}{lcc}
\multicolumn{1}{c}{ Nilai IKM } & Kategori Kepuasan & Kategori Mutu Layanan \\
\hline $25,00-43,75$ & Sangat Tidak Puas & Sangat Tidak Baik \\
\hline $43,76-62,50$ & Tidak Puas & Tidak Baik \\
\hline $62,51-81,25$ & Puas & Baik \\
\hline $81,26-100,00$ & Sangat Puas & Sangat Baik
\end{tabular}

\section{HASIL PENELITIAN DAN PEMBAHASAN}

\section{A. Hasil Penelitian}

\section{Pelayanan Akademik Keuangan}

Pengelolaan keuangan Akper Dirgahayu berada langsung di bawah Wakil Direktur II. Pengelola terdiri atas Kepala Urusan (Kaur) keuangan dan dibantu oleh dua orang staf. Kaur keuangan bertugas mengkoordinasikan pengelolaan urusan keuangan dan bertanggung jawab langsung kepada Wakil Direktur II, tugas masing-masing staf adalah menangani dua urusan yakni urusan gaji serta SPP mahasiswa dan urusan akunting dan bertanggung jawab langsung kepada Kaur Keuangan.

Sistem pembayaran SPP di AKPER Dirgahayu dilakukan setiap awal semester melalui Bank Tabungan Negara
(BTN) dan harus dilunasi sebelum mengikuti perkuliahan pada semester tersebut. Bagi mahasiswa yang tidak mampu, manajemen membuat kebijakan dengan memberikan kelonggaran kepada mahasiswa dengan cara mencicil setiap bulan.

Alur pelayanan kepada mahasiswa disajikan dalam bentuk bagan yang ditempel di depan ruang keuangan, sebagai berikut; mahasiswa datang ke BTN dengan mengisi formulir penyetoran biaya kuliah, menyetor dana melalui BTN, bukti pembayaran yang telah diverifikasi oleh BTN di foto copy dan diserahkan kepada urusan SPP.

Fasilitas yang disediakan dalam pelayanan SPP adalah 1 buah meja dan 1 buah kursi untuk mengisi formulir penyetoran SPP. 
2. Kepuasan Mahasiswa Terhadap Pelayanan

Berdasarkan prosedur perhitungan, hasil perhitungan Indeks
Kepuasan Mahasiswa (IKM) terhadap pelayanan secara umum dan terhadap setiap dimensi pelayanan dirangkum dalam Tabel 2.

\section{Tabel 2. Hasil Perhitungan IKM terhadap Pelayanan}

\begin{tabular}{clccc} 
No. & Dimensi Pelayanan & IKM & Kategori & Peringkat \\
\hline 1 & Tangibles & 71,00 & puas & 1 \\
\hline 2 & Responsivness & 66,70 & puas & 5 \\
\hline 3 & Realibility & 69,20 & puas & 2 \\
\hline 4 & Emphaty & 69,10 & puas & 3 \\
\hline 5 & Assurance & 66,80 & puas & 4 \\
\hline & Total & 68,90 & puas &
\end{tabular}

Terlihat nilai IKM total sebesar 68,90 yang tergolong kategori puas. Hasil tersebut menunjukkan bahwa secara umum mahasiswa merasa puas perhadap pelayanan oleh staf administrasi akademik keuangan, dan juga berarti bahwa mutu pelayanan staf administrasi akademik keuangan Akper Dirgahayu tergolong kategori baik.

Kepuasan mahasiswa dan mutu pelayanan yang berlaku terhadap total pelayanan juga berlaku terhadap setiap dimensi pelayanan, terlihat bahwa setiap dimensi pelayanan memiliki nilai IKM yang tergolong kategori puas di mana yang paling tinggi adalah dimensi tangibles. Terlihat pula bahwa dimensi responsivness dan dimensi assurance memiliki nilai IKM lebih rendah dari IKM total.

Gambaran kepuasan terhadap pelayanan secara distribusi persentase berdasarkan skor angket skala kepuasan yang diperoleh mahasiswa disajikan pada Tabel 3 berikut.

Tabel 3. Distribusi Mahasiswa Berdasarkan Kategori Kepuasan Terhadap Total Pelayanan

\begin{tabular}{ccc} 
Kategori & Jumlah & Persentase \\
\hline Sangat Tidak Puas & 5 & 2,70 \\
Tidak Puas & 51 & 27,60 \\
Puas & 103 & 55,60 \\
Sangat Puas & 26 & 14,10 \\
\hline Total & 185 & 100,00
\end{tabular}

Tampak bahwa mahasiswa yang memiliki persepsi yang tergolong kategori puas terhadap pelayanan staf administasi akademik keuangan adalah jumlah paling banyak yakni sebesar 55,60 persen dan ada 14,10 persen yang persepsinya tergolong kategori sangat puas. Tampak pula bahwa ada yang memiliki persepsi tergolong kategori tidak puas dan sangat tidak puas yakni sekitar 30,30 persen.

Distribusi persentase tersebut, bahwa sekitar 69,70 persen mahasiswa memiliki persepsi yang tergolong kategori puas dan sangat puas, mendukung nilai IKM total untuk menyimpulkan bahwa secara umum mahasiswa merasa puas perhadap pelayanan oleh staf administrasi akademiki keuangan dan sekaligus bahwa secara umum mutu pelayanan staf administrasi akademiki keuangan Akper Dirgahayu tergolong kategori baik menurut persepsi mahasiswa.

2. Kepuasan Mahasiswa terhadap Item-Item Pelayanan

Deskripsi secara detail tentang kepuasan mahasiswa terhadap pelayanan dan mutu pelayanan adalah hasil perhitungan nilai IKM terhadap item-item pelayanan yang disajikan pada Tabel 4.

Tabel 4. Hasil Perhitungan IKM Terhadap Item-item Pelayanan 


\begin{tabular}{clccc} 
No. & Item Pelayanan & IKM & Kategori & Peringkat \\
\hline 1 & Penampilan petugas & 71,60 & puas & 4 \\
\hline 2 & Kemudahan menemui petugas & 67,10 & puas & 12 \\
\hline 3 & Kemudahan mengakses loket & 71,50 & puas & 5 \\
\hline 4 & Ketersediaan alur pelayanan & 74,00 & puas & 1 \\
\hline 5 & Kesigapan menanyakan kebutuhan & 65,50 & puas & 14 \\
\hline 6 & Keramahan petugas & 62,60 & puas & 15 \\
\hline 7 & $\begin{array}{l}\text { Kesigapan petugas menjelaskan } \\
\text { informasi }\end{array}$ & 72,10 & puas & 2 \\
\hline 8 & Kecepatan pelayanan & 67,20 & puas & 11 \\
\hline 9 & Keadilan pelayanan & 71,40 & puas & 6 \\
\hline 10 & Kemudahan prosedur pelayanan & 69,00 & puas & 7 \\
\hline 11 & $\begin{array}{l}\text { Kesediaan petugas membantu } \\
\text { kesulitan }\end{array}$ & 67,40 & puas & 10 \\
\hline 12 & $\begin{array}{l}\text { Kecakapan Petugas Memberi } \\
\text { Penjelasan }\end{array}$ & 71,90 & puas & 3 \\
\hline 13 & Ketepatan janji petugas & 68,00 & puas & 8 \\
\hline 14 & $\begin{array}{l}\text { Setiap permintaan layanan selalu } \\
\text { terpenuhi }\end{array}$ & 65,80 & puas & 13 \\
\hline 15 & $\begin{array}{l}\text { Kemampuan Petugas Memberikan } \\
\text { Solusi }\end{array}$ & 67,80 & puas & 9 \\
\hline & Total pelayanan & 68,90 & puas & \\
\hline
\end{tabular}

Berdasarkan Tabel 4 di atas tampak bahwa semua item pelayanan memiliki nilai IKM tergolong kategori puas, yang berarti bahwa secara umum mahasiswa merasa puas terhadap semua item pelayanan dan juga berarti bahwa menurut mereka mutu semua item pelayanan tergolong baik. Selanjutnya, gambaran kepuasan mahasiswa berdasarkan persepsi terhadap item-item pelayanan disajikan dengan distribusi persentase yang disajikan pada Tabel 5.

Tabel 5. Distribusi Mahasiswa Berdasarkan Persepsi terhadap Item-item Pelayanan Penampilan Petugas

\begin{tabular}{ccc}
\hline Persepsi & Jumlah & Persentase \\
\hline Sangat Tidak Puas & 6 & 3,20 \\
Tidak Puas & 44 & 23,80 \\
Puas & 104 & 56,20 \\
Sangat Puas & 31 & 16,80 \\
\hline Total & 185 & 100,00 \\
\hline \multicolumn{3}{c}{ Kemudahan Menemui Petugas } \\
\hline Persepsi & Jumlah & Persentase \\
\hline Tidak Menjawab & 6 & 3,20 \\
Sangat Tidak Puas & 4 & 2,20 \\
Tidak Puas & 55 & 29,70 \\
Puas & 100 & 54,10 \\
Sangat Puas & 20 & 10,80 \\
\hline Total & 185 & 100,00 \\
\hline Persepsi & Kemudahan Mengakses Loket Pembayaran \\
\hline Tidak Menjawab & 2 & Persentase \\
Sangat Tidak Puas & 1 & 1,10 \\
& & 0,50
\end{tabular}




\begin{tabular}{|c|c|c|}
\hline Tidak Puas & 41 & 22,20 \\
\hline Puas & 121 & 65,40 \\
\hline Sangat Puas & 20 & 10,80 \\
\hline Total & 185 & 100,00 \\
\hline \multicolumn{3}{|c|}{ Ketersediaan Alur Pelayanan } \\
\hline Persepsi & Jumlah & Persentase \\
\hline Tidak Menjawab & 16 & 8,60 \\
\hline Sangat Tidak Puas & 3 & 1,60 \\
\hline Tidak Puas & 25 & 13,50 \\
\hline Puas & 117 & 63,20 \\
\hline Sangat Puas & 24 & 13,00 \\
\hline Total & 185 & 100,00 \\
\hline \multicolumn{3}{|c|}{ Kesigapan menanyakan kebutuhan } \\
\hline Persepsi & Jumlah & Persentase \\
\hline Sangat Tidak Puas & 13 & 7,00 \\
\hline Tidak Puas & 64 & 34,60 \\
\hline Puas & 88 & 47,60 \\
\hline Sangat Puas & 20 & 10,80 \\
\hline Total & 185 & 100,00 \\
\hline \multicolumn{3}{|c|}{ Keramahan petugas } \\
\hline Persepsi & Jumlah & Persentase \\
\hline Tidak Menjawab & 1 & 0,50 \\
\hline Sangat Tidak Puas & 17 & 9,20 \\
\hline Tidak Puas & 76 & 41,10 \\
\hline Puas & 70 & 37,80 \\
\hline Sangat Puas & 21 & 11,40 \\
\hline Total & 185 & 100,00 \\
\hline \multicolumn{3}{|c|}{ Kesigapan petugas menjelaskan informasi } \\
\hline Persepsi & Jumlah & Persentase \\
\hline Tidak Menjawab & 3 & 1,60 \\
\hline Sangat Tidak Puas & 10 & 5.40 \\
\hline Tidak Puas & 35 & 18,90 \\
\hline Puas & 100 & 54,10 \\
\hline Sangat Puas & 37 & 20,00 \\
\hline Total & 185 & 100,00 \\
\hline \multicolumn{3}{|c|}{ Kecepatan pelayanan } \\
\hline Persepsi & Jumlah & Persentase \\
\hline Sangat Tidak Puas & 9 & 4,80 \\
\hline Tidak Puas & 59 & 31,90 \\
\hline Puas & 98 & 53,00 \\
\hline Sangat Puas & 19 & 10,30 \\
\hline Total & 185 & 100,00 \\
\hline \multicolumn{3}{|c|}{ Keadilan pelayanan } \\
\hline Persepsi & Jumlah & Persentase \\
\hline Tidak Menjawab & 1 & 0,50 \\
\hline Sangat Tidak Puas & 10 & 5,40 \\
\hline Tidak Puas & 31 & 16,80 \\
\hline Puas & 116 & 62,70 \\
\hline Sangat Puas & 27 & 14,60 \\
\hline
\end{tabular}




\begin{tabular}{|c|c|c|}
\hline Total & 185 & 100,00 \\
\hline \multicolumn{3}{|c|}{ Kemudahan/Kesesuaian Prosedur Pelayanan } \\
\hline Persepsi & Jumlah & Persentase \\
\hline Tidak Menjawab & 1 & 0,50 \\
\hline Sangat Tidak Puas & 7 & 3,80 \\
\hline Tidak Puas & 51 & 27,60 \\
\hline Puas & 105 & 56,80 \\
\hline Sangat Puas & 21 & 11,40 \\
\hline Total & 185 & 100,00 \\
\hline \multicolumn{3}{|c|}{ Kesediaan Petugas Membantu Kesulitan } \\
\hline Persepsi & Jumlah & Persentase \\
\hline Tidak Menjawab & 1 & 0,50 \\
\hline Sangat Tidak Puas & 11 & 5,90 \\
\hline Tidak Puas & 55 & 29,80 \\
\hline Puas & 97 & 52,40 \\
\hline Sangat Puas & 21 & 11,40 \\
\hline Total & 185 & 100,00 \\
\hline \multicolumn{3}{|c|}{ Kecakapan Petugas Memberi Penjelasan } \\
\hline Persepsi & Jumlah & Persentase \\
\hline Sangat Tidak Puas & 7 & 3,80 \\
\hline Tidak Puas & 34 & 18,40 \\
\hline Puas & 119 & 64,30 \\
\hline Sangat Puas & 25 & 13,50 \\
\hline Total & 185 & 100,00 \\
\hline \multicolumn{3}{|c|}{ Ketepatan Janji Petugas } \\
\hline Persepsi & Jumlah & Persentase \\
\hline Sangat Tidak Puas & 7 & 3,80 \\
\hline Tidak Puas & 55 & 29,70 \\
\hline Puas & 106 & 57,30 \\
\hline Sangat Puas & 17 & 9,20 \\
\hline Total & 185 & 100,00 \\
\hline \multicolumn{3}{|c|}{ Setiap Permintaan Layanan Selalu Terpenuhi } \\
\hline Persepsi & Jumlah & Persentase \\
\hline Tidak Menjawab & 4 & 2,20 \\
\hline Sangat Tidak Puas & 11 & 5,90 \\
\hline Tidak Puas & 54 & 29,20 \\
\hline Puas & 101 & 54,60 \\
\hline Sangat Puas & 15 & 8,10 \\
\hline Total & 185 & 100,00 \\
\hline \multicolumn{3}{|c|}{ Kemampuan Petugas Memberikan Solusi } \\
\hline Persepsi & Jumlah & Persentase \\
\hline Tidak Menjawab & 4 & 2,20 \\
\hline Sangat Tidak Puas & 11 & 5,90 \\
\hline Tidak Puas & 51 & 27,50 \\
\hline Puas & 93 & 50,30 \\
\hline Sangat Puas & 26 & 14,10 \\
\hline Total & 185 & 100,00 \\
\hline
\end{tabular}


Penampilan (kerapian dan kebersihan) petugas pada saat memberikan pelayanan, 73,0 persen mahasiswa memiliki persepsi puas dan sangat puas, dan 27,0 persen tidak puas dan sangat tidak puas.

Kemudahan menemui petugas, yaitu terhadap pernyataan "saya langsung bisa bertemu petugas ketika datang" 64,90 persen mahasiswa memiliki persepsi puas dan sangat puas, 31,90 persen tidak puas dan sangat tidak puas, dan 3,20 persen tidak memberikan tanggapan.

Pada item kemudahan mengakses loket pembayaran, 76,20 persen mahasiswa memiliki persepsi puas dan sangat puas, 22,70 persen tidak puas dan sangat tidak puas, dan 1,10 persen tidak memberikan tanggapan.

Pada item ketersediaan alur pelayanan di bagian keuangan, 76,20 persen mahasiswa memiliki persepsi puas dan sangat puas, 15,10 persen tidak puas dan sangat tidak puas, dan 8,60 persen mahasiswa tidak memberikan tanggapan.

Terhadap pernyataan "petugas selalu menanyakan apa kebutuhan mahasiswa", 58,40 persen mahasiswa memiliki persepsi puas dan sangat puas, dan 41,60 persen tidak puas dan sangat tidak puas.

Terhadap pernyataan "petugas selalu menyambut mahasiswa dengan senyum", 49,20 persen mahasiswa memiliki persepsi puas dan sangat puas, 50,30 persen tidak puas dan sangat tidak puas, dan 1 orang atau 0,50 persen tidak memberikan tanggapan.

Terhadap pernyataan "jika ditanya informasi yang kurang jelas petugas segera menjelaskan", 74,10 persen mahasiswa memiliki persepsi puas dan sangat puas, 24,30 persen tidak puas dan sangat tidak puas, dan 1,60 persen mahasiswa tidak memberikan tanggapan.

Terhadap pernyataan "pelayanan yang diberikan kepada saya selalu terselesaikan dengan cepat", 63,30 persen mahasiswa memiliki persepsi puas dan sangat puas, dan 36,70 persen tidak puas dan sangat tidak puas.
Terhadap pernyataan "petugas selalu adil dalam melayani konsumen yang datang sesuai urutan", 77,30 persen mahasiswa memiliki persepsi puas dan sangat puas, 22,20 persen tidak puas dan sangat tidak puas, dan 1 orang atau 0,50 persen tidak memberikan tanggapan.

Pada item kemudahan/kesesuaian prosedur pelayanan", 68,20 persen mahasiswa memiliki persepsi puas dan sangat puas, 31,40 persen tidak puas dan sangat tidak puas, dan 1 orang atau 0,50 persen tidak memberikan tanggapan.

Terhadap pernyataan "petugas selalu bersedia membantu ketika saya mendapatkan kesulitan", 63,80 persen mahasiswa memiliki persepsi puas dan sangat puas, 35,60 persen tidak puas dan sangat tidak puas, dan 1 orang atau 0,50 persen tidak memberikan tanggapan.

Pada item kecakapan petugas pemberikan penjelasan dalam pelayanan sehingga mudah dimengerti, 77,80 persen mahasiswa memiliki persepsi puas dan sangat puas, dan 22,20 persen tidak puas dan sangat tidak puas.

Terhadap ketepatan janji petugas dalam memberikan pelayanan, 66,50 persen mahasiswa memiliki persepsi puas dan sangat puas, dan 33,50 persen tidak puas dan sangat tidak puas.

Terhadap pernyataan "setiap layanan yang saya minta selalu terpenuhi", 62,70 persen mahasiswa memiliki persepsi puas dan sangat puas, 35,10 persen tidak puas dan sangat tidak puas, dan 2,20 persen tidak memberikan tanggapan.

Terhadap pernyataan "jika layanan yang saya terima tidak bisa selesai di bagian keuangan, petugas selalu memberi solusi", 64,40 persen mahasiswa memiliki persepsi puas dan sangat puas, 33,40 persen tidak puas dan sangat tidak puas, dan 2,20 persen tidak memberikan tanggapan.

\section{B. Pembahasan}

Salah satu modal sebuah perguruan tinggi untuk merekrut calon-calon mahasiswa adalah reputasinya yakni 
profesionalisme dalam memberikan jasa atau layanan pendidikan kepada mahasiswa. Peran mahasiswa sebagai pelanggan sekaligus sebagai anggota masyarakat, menyebabkan informasi reputasi sebuah perguruan tinggi lebih cepat diketahui masyarakat umum secara luas. Kualitas layanan pendidikan ditentukan oleh fasilitas kampus, kompetensi dosen dan karyawan, dan mutu pelayanan oleh staf administrasi/karyawan. Bagi Akper Dirgahayu yang telah menerapkan standar pendidikan keperawatan nasional dan mendapat penilaian akreditasi B dari BAN-PT, fasilitas kampus dan kompetensi dosen dan karyawan tidak diragukan lagi, aspek layanan yang belum diketahui kualitasnya secara pasti adalah mutu pelayanan oleh para staf administrasi/karyawan khususnya di bagian akademik keuangan, dan merupakan hal yang melatarbelakangi penelitian ini.

Mutu pelayanan direpresentasikan oleh tingkat kepuasan mahasiswa terhadap pelayanan yang diberikan oleh staf administrasi bagian keuangan yang diukur menggunakan skala kepuasan. Tingkat kepuasan dideskripsikan menggunakan Indeks Kepuasan Mahasiswa (IKM) dan distribusi persentase mahasiswa berdasarkan kategori kepuasan, terhadap pelayanan secara total, terhadap dimensi pelayanan, dan secara detail terhadap itemitem pelayanan.

Hasil perhitungan diperoleh nilai IKM total sebesar 68,90 yang tergolong kategori puas. Nilai IKM terhadap dimensi pelayanan dan nilai IKM terhadap itemitem pelayanan juga tergolong kategori puas. Hasil perhitungan nilai IKM tersebut didukung oleh distribusi persentase bahwa sekitar 70 persen mahasiswa tergolong kategori puas dan sangat puas. Kedua besaran tersebut menunjukkan secara umum mahasiswa merasa puas perhadap pelayanan oleh staf administrasi keuangan dan juga sebagai dasar promosi kepada masyarakat khususnya kepada calon-calon mahasiswa.

Mutu pelayanan staf administrasi akademik keuangan yang sudah tergolong baik tersebut, pada masa yang akan datang masih memungkinkan untuk ditingkatkan lagi oleh pihak manajemen Akper Dirgahayu. Celah untuk melakukan perbaikan kualitas pelayan didasarkan pada persepsi mahasiswa terhadap item-item pelayanan, yakni dengan memprioritaskan perhatian terhadap item/pernyataan yang potensial dipersepsikan tidak puas dan sangat tidak puas oleh mahasiswa, dan dengan mempertimbangkan saran dari mahasiswa yang dicantumkan dalam kuesiner. Hanya saja, patut disayangkan karena hanya 56 orang mahasiswa atau sekitar 30 persen yang memberikan saran dan itupun hanya terkait dengan item pelayanan tertentu saja.

Berdasarkan distribusi persentase, item-item pelayanan yang potensial dipersepsikan tidak puas dan sangat tidak puas oleh mahasiswa adalah keramahan petugas, kemudahan menemui petugas, kesigapan menanyakan kebutuhan, kecepatan pelayanan, kemudahan/kesesuaian prosedur pelayanan, kesediaan petugas membantu kesulitan, ketepatan janji petugas, setiap permintaan layanan selalu terpenuhi, dan kemampuan petugas memberikan solusi. Masing-masing item pelayanan tersebut dipersepsikan tidak puas dan sangat tidak puas oleh lebih dari 30 persen mahasiswa, sehingga pihak manajemen Akper Dirgahayu dituntut memprioritaskan perhatian/perbaikan terhadap item-item tersebut guna peningkatan mutu pelayanan secara umum.

Persepsi tidak puas terhadap suatu item pelayanan tidak serta merta menunjukkan bahwa item tersebut dalam prakteknya buruk. Penyebab ketidakpuasan; selain karena faktor petugas, bisa saja terjadi karena ketidakpahaman sehingga keliru mempersepsikan, bisa juga karena mahasiswa menuntut 
pelayanan yang lebih, sementara petugas dibatasi oleh aturan, atau karena kondisi psikologis pada saat transaksi layanan. Kecepatan pelayanan misalnya, item ini memiliki nilai IKM di bawah IKM total dan dipersepsikan tidak puas/sangat tidak puas oleh 36,70 persen mahasiswa. Hal yang perlu disadari bahwa aturan pengelolaan keuangan ditangani oleh petugas tertentu saja dan bekerjanya harus ekstra hati-hati karena kesalahan kecil saja bisa berakibat fatal, karena itu pelayanan keuangan wajar kalau terkesan lama dan mahasiswa harus antre. Untuk mengatasi hal ini, hendaknya petugas memperhatikan item pelayanan ini sambil tetap hati-hati dan mentaati aturan/prosedur pengelolaan keuangan dan kepada mahasiswa supaya melakukan pembayaran bukan pada harihari terakhir dari batas waktu yang ditentukan agar tidak lama mengantre.

Demikian juga dengan kemudahan/kesesuaian prosedur pelayanan, item ini dipersepsikan tidak puas dan sangat tidak puas oleh 31,40 persen mahasiswa. Diharapkan mahasiswa bersabar mengikuti prosedur yang ada karena pihak Akper Dirgahayu menerapkan prosedur standar pengelolaan keuangan yang juga berlaku di perguruan tinggi lain. Beberapa mahasiswa yang tidak puas terhadap item pelayanan ini menyarankan agar tagihan pembayaran tidak ditempel di papan pengumuman. Pihak manajemen Akper Dirgahayu sebaiknya memberikan kesempatan kepada mahasiswa yang belum bisa melunasi pembayaran sampai batas waktu yang ditentukan untuk menghadap dan mengkomunikasikan hal tersebut lebih lanjut. Di sisi lain, mahasiswa hendaknya menyadari sebuah keberuntungan yang jarang ditemui di perguruan tinggi lain yakni kebijakan manajemen Akper Dirgahayu memberikan kesempatan kepada mahasiswa boleh mengangsur (cicil) pembayaran uang kuliah. Mahasiswa juga perlu menyadari bahwa penyelenggaraan pendidikan ditopang oleh pembiayaan terencana yang mana di dalamnya sudah memperhitungkan pembayaran uang kuliah, keterlambatan pembayaran uang kuliah bukan tidak mungkin akan merepotkan pengelola mencari dana talangan.

Keramahan petugas dalam memberikan pelayanan adalah item yang hendaknya mendapat perhatian utama pihak manajemen Akper Dirgahayu guna meningkatkan mutu pelayanan. Item pelayanan ini memiliki nilai IKM paling rendah, memiliki persentase persepsi tidak puas dan sangat tidak puas paling besar yakni 50,30 persen, dan paling banyak mendapat saran/keluhan. Mahasiswa yang memiliki persepsi tidak puas dan sangat tidak puas terhadap item ini menyarankan agar petugas bersikap ramah, banyak senyum, sabar, dan tidak marah atau terkesan marah ketika memberikan pelayanan. Membenahi item pelayanan ini, diharapkan berdampak positif bagi kualitas item pelayanan lainnya antara lain kesediaan petugas membantu kesulitan, ketepatan janji petugas, setiap permintaan layanan selalu terpenuhi, dan kemampuan petugas memberikan solusi.

Kesigapan petugas menanyakan kebutuhan mahasiswa adalah item pelayanan yang memiliki nilai IKM peringkat kedua dari bawah dan memiliki persentase persepsi tidak puas dan sangat tidak puas cukup besar yakni 41,60 persen. Kemungkinan hal tersebut adalah karena petugas sudah tahu tujuan mahasiswa mendatangi loket pembayaran sehingga tidak perlu bertanya, atau mahasiswa mengemukakan tujuannya terlebih dahulu sebelum petugas bertanya, atau mungkin juga petugas menanyakan kebutuhan mahasiswa tetapi terkesan tidak ramah bagi mahasiswa. Memperbaiki item keramahan petugas, juga diharapkan akan mengubah persepsi mahasiswa terhadap item pelayanan ini.

Kemudahan menemui petugas adalah item pelayanan yang tidak kalah penting dibanding item lain. Keramahan dan kecakapan seorang petugas menjadi tidak berarti jika sulit ditemui ketika 
dibutuhkan oleh mahasiswa. Item ini juga perlu mendapat perhatian serius dari pihak manajemen Akper Dirgahayu guna peningkatan mutu pelayanan. Berdasarkan hasil perhitungan, Item ini memiliki nilai IKM lebih rendah dari IKM total dan dipersepsikan tidak puas dan sangat tidak puas oleh 31,90 persen mahasiswa. Beberapa mahasiswa menyarankan agar petugas selalu berada ditempat dan tidak membuat mereka menunggu. Petugas loket yang terkadang tidak sedang berada ditempat juga terjadi di instansi lain, yang bersangkutan biasanya berada di ruang pimpinan

mendiskusikan/mengkonsultasikan masalah keuangan dan berlangsung cukup lama sementara tugasnya di loket tidak boleh digantikan petugas lain. Karena itu, jadwal pertemuan antara pimpinan dan petugas loket sebaiknya diatur sehingga tidak menyita waktu pelayanan kepada mahasiswa.

Keadilan petugas dalam memberikan pelayanan adalah item yang memiliki nilai IKM cukup tinggi dan lebih tinggi dari pada IKM total, namun item ini juga perlu mendapat perhatian khusus. Terhadap pernyataan "petugas selalu adil dalam melayani konsumen yang datang sesuai urutan", 22,20 persen mahasiswa memiliki persepsi tidak puas dan sangat tidak. Beberapa diantara mahasiswa tersebut menyarankan agar petugas melayani sesuai dengan urutan antrean, tidak mendahulukan pelayanan bagi yang akan membayar lunas.

\section{KESIMPULAN DAN SARAN}

\section{Kesimpulan}

1. Kepuasan mahasiswa terhadap pelayanan staf administrasi bagian keuangan Akper Dirgahayu tergolong kategori puas, nilai indeks kepuasan mahasiswa (IKM) terhadap total pelayanan sebesar 68,90 (tergolong kategori puas) dan sekitar 70 persen mahasiswa memiliki skor kepuasan
Penampilan petugas dalam pelayanan adalah item pelayanan yang juga memiliki nilai IKM cukup tinggi dan lebih tinggi dari pada IKM total dan persepsi tidak puas dan sangat tidak puas terhadap item ini tidak sampai 30 persen, namun item ini banyak mendapat saran dari mahasiswa. Mereka menyarankan agar kebersihan dan kerapian petugas lebih ditingkatkan lagi, termasuk didalamnya kerapian rambut. Mahasiswa penelitian ini adalah calon-calon perawat yang sudah dibekali ilmu kesehatan sehingga lebih cermat mempersepsikan kebersihan, boleh jadi bersih dan rapi menurut orang lain tapi belum cukup menurut mereka.

Item-item pelayanan yang juga memiliki nilai IKM cukup tinggi dan lebih tinggi dari pada IKM total adalah kemudahan mengakses loket, ketersediaan alur pelayanan, kesigapan petugas menjelaskan informasi, dan kecakapan petugas memberi penjelasan. Beberapa mahasiswa mempersepsikan tidak puas namun tidak ada yang memberikan saran untuk perbaikan, sehingga pihak manajemen Akper Dirgahayu setidaktidaknya mempertahankan kualitas yang sudah ada. Memberikan perhatian terhadap item-item lain yang potensial dipersepsikan tidak puas, diharapkan akan mengubah persepsi mahasiswa yang memiliki persepsi tidak puas terhadap item-item tersebut khususnya kesigapan petugas menjelaskan informasi dan kecakapan petugas memberi penjelasan.

tergolong kategori puas dan sangat puas.

2. Kepuasan terhadap semua dimensi pelayanan dan terhadap semua item pelayanan juga memiliki nilai IKM tergolong kategori puas. Hasil tersebut adalah representasi dari mutu setiap item pelayanan semuanya tergolong baik menurut persepsi mahasiswa.

3. Meskipun mutu semua item pelayanan tergolong baik, namun beberapa item diantaranya potensial dipersepsikan 
tidak puas oleh mahasiswa. Item-item tersebut adalah keramahan petugas, kemudahan menemui petugas, kesigapan menanyakan kebutuhan, kecepatan pelayanan, kemudahan/kesesuaian prosedur pelayanan, keadilan petugas, kesediaan petugas membantu kesulitan, ketepatan janji petugas, setiap permintaan layanan selalu terpenuhi, dan kemampuan petugas memberikan solusi. Masing-masing item tersebut dipersepsikan tidak puas dan sangat tidak puas lebih dari 30 persen mahasiswa.

\section{Saran}

Sebagai implikasi dari kesimpulan penelitian, berikut ini dikemukakan beberapa saran.

1. Pihak manajemen supaya mengatur jadwal pertemuan antara pimpinan dan petugas loket yang tidak menyita waktu pelayanan kepada mahasiswa dan supaya memberikan kesempatan kepada mahasiswa yang belum bisa

\section{DAFTAR PUSTAKA}

Alfiani, Arifah. 2016. Kepuasan Mahasiswa Terhadap Pelayanan Administrasi Akademik di Subbag Pedidikan Fakultas Ilmu Pendidikan Universitas Yogyakarta. Skripisi. Program Studi Manajemen Pendidikan Jurusan Administrasi Pendidikan Jurusan Ilmu Pendidikan Universitas Yogyakarta.

Anonim. 2012. Indeks Kepuasan Masyarakat (Pengguna Jasa) Universitas Brawijaya. Pusat Informasi, Dokumentasi, dan Keluhan Universitas Brawijaya Malang melunasi pembayaran sampai batas waktu yang ditentukan untuk menghadap dan mengkomunikasikan hal tersebut lebih lanjut.

2. Petugas bagian keuangan khususnya yang berinteraksi langsung dengan mahasiswa supaya lebih bersikap ramah dan murah senyum, menjaga kebersihan dan kerapian penampilan, dan mendahulukan pelayanan menurut antrean.

3. Mahasiswa supaya memahami bahwa petugas yang menangani keuangan hanya petugas tertentu dan berkerja dengan ekstra hati-hati sehingga terkesan lambat, berusaha supaya tidak terlambat membayar uang kuliah karena penyelenggaraan pendidikan ditopang oleh pembiayaan terencana yang di dalamnya sudah memperhitungkan pembayaran uang kuliah, dan berusaha supaya melakukan pembayaran bukan pada hari-hari terakhir dari batas waktu yang ditentukan agar tidak lama mengantre.

Endang, Fatmawati. 2003. Analisis Kualitas Pelayanan Pada Bagian Administrasi Fakultas Ekonomi UNDIP. Tesis. Universitas Diponegoro, Semarang.

Gronroos, Christian. 1990. Service Management and Marketing; A Moment of Truth. Maxwell Macmillan International, Singapura.

Irawan, H. 2002. 10 Prinsip Kepuasan Pelanggan. Elex Media Komputindo Gramedia, Jakarta.

Kotler dan Keller 2009. Majajemen Pemasaran. Jilid I. Edisi ke 13. Jakarta. Erlangga.

Maisaroh, Siti. 2005. Pengaruh Manajemen Mutu Layanan 
terhadap Kepuasan Peserta Didik di Universitas PGRI Yogyakarta. Laporan Penelitian.Universitas PGRI Yogyakarta.

Marzuki, Mahmud. 2012. Manajemen Mutu Perguruan Tinggi. Raja Grafindo Persada, Jakarta..

Sinta, Hadiyantina. 2012. Pelayanan Prima Di Dalam Dunia Kependidikan. Materi: Disampaikan pada Workshop Peningkatan Kinerja Tenaga
Kependidikan. Fakultas Hukum Universitas Brawijaya Malang.

Sukanti. 2009. Analisis Kepuasan Mahasiswa Program Studi Pendidikan Akuntansi FISE UNY. Jurnal Pendidikan Akuntansi Indonesia (Vol. Viii. Nomor 1). Hal $23-3$.

Yahya, Sudarya. 2007. Service Quality Satisfaction dalam Layanan Pendidikan : Kajian Teoritis. Jurnal Pendidikan Dasar Nomor 8. 